\title{
DAMPAK PANDEMI COVID-19 TERHADAP MANAJEMEN INDUSTRI PERBANKAN SYARIAH: ANALISIS KOMPARATIF
}

\author{
Mardhiyaturrositaningsih ${ }^{1}$, Muhammad Syarqim Mahfudz ${ }^{2}$ \\ ${ }^{1}$ Program Studi Perbankan Syariah, Fakultas Ekonomi dan Bisnis Islam, UIN Walisongo Semarang \\ ${ }^{2}$ Program Studi Teknik Industri, Fakultas Teknik, Universitas Gadjah Mada Yogyakarta \\ Email ${ }^{1}$ mardhiyaturrositaningsih@walisongo.ac.id, ${ }^{2}$ syarqimmahfudz@gmail.com
}

\begin{abstract}
ABSTRAK
Data Kementrian Kesehatan menunjukkan total kasus terkonfirmasi COVID-19 di Indonesia adalah 9.771 kasus dengan jumlah kematian 784 jiwa. Provinsi Jakarta dan Jawa Barat adalah daerah dengan jumlah kasus Covid-19 tertinggi. Ini adalah tantangan bagi dunia bisnis, termasuk Bank Syariah, yang berdasarkan data Statistik perbankan Syariah menunjukkan bahwa Jakarta sebagai wilayah dengan jumlah jaringan kantor cabang Bank Syariah terbanyak di Indonesia. Penelitian ini merupakan analisis komparatif yang bertujuan untuk mengetahui dampak pandemi Covid-19 pada industri perbankan dari sisi Manajemen strategi operasional Bank dan Kegiatan Intermediasi Bank. Penelitian menggunakan sampel 5 Bank Umum Syariah. Sampel penelitian dipilih menggunakan teknik purposive sampling. Hasil penelitian menunjukkan bahwa pada Desember sampai Maret 2020 semua bank mengalami gejolak pada fungsi intermediasinya yang cenderung menurun baik dari pembiayaan maupun penghimpunan dana. Sementara itu, dalam hal Manajemen Strategi Bank Syariah menerapkan berbagai kebijakan diantaranya pembatasan layanan melalui tatap muka langsung, memberikan kebijakan restrukturisasi kepada nasabah yang tedampak dan pemanfaatan aplikasi digital.
\end{abstract}

Kata Kunci: Covid-19, Industri Perbankan Syariah, Manajemen

\begin{abstract}
Ministry of Health data shows the total confirmed cases of COVID-19 in Indonesia is 9,771 cases with a total of 784 deaths. Jakarta and West Java provinces are the regions with the highest number of Covid-19 cases. This is a challenge for the business world, including Sharia Banks, which based on Sharia banking Statistics data show that Jakarta is the region with the largest number of Sharia Bank branch offices in Indonesia. This study is a comparative analysis which aims to determine the impact of the Covid-19 pandemic on the banking industry on the side of the management of the Bank's operational strategies and Bank Intermediation Activities. The study used a sample of 5 Islamic Commercial Banks. The research sample was selected using purposive sampling technique. The results showed that in December to March 2020 all banks experienced turmoil in the intermediation function which tended to decline both from funding and fund raising. Meanwhile, in terms of Sharia Bank Strategy Management implementing a variety of policies including service restrictions through face-to-face, providing restructuring policies to affected customers and utilizing digital applications.
\end{abstract}

Keywords: Covid-19, Islamic Banking Industry, Management 


\section{A. PENDAHULUAN}

Coronavirus Disease 2019 atau disebut Covid19 adalah penyakit menular yang menyebabkan penyakit paru-paru serius. Kasus Covid-19 ditemukan pertama kali di Tiongkok pada November 2019. Covid-19 diketahui sebagai penyakit menular yang disebabkan oleh virus baru dengan tingkat persebaran sangat cepat. Seperti dilaporkan oleh Organisasi Kesehatan Dunia (WHO), total kasus Covid-19 yang terkonfirmasi di seluruh dunia adalah sebanyak 3.116.398 kasus dengan kematian 217.153 jiwa (29 April 2020). Indonesia adalah negara dengan jumlah kematian terbesar akibat Covid-19 di antara negara-negara ASEAN lainnya, diikuti oleh Filipina dan Malaysia di posisi kedua dan ketiga seperti yang ditunjukkan pada Gambar 1.

Gambar 1. Covid-19 Kasus: Kematian di Negara ASEAN

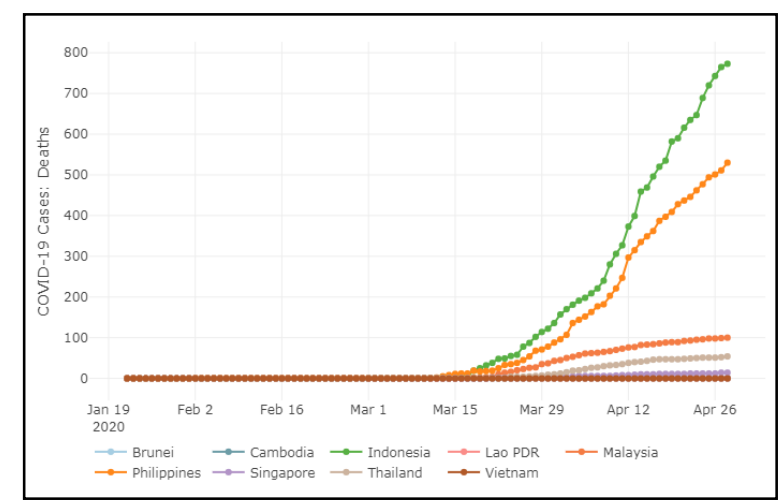

Sumber: 29 April 2020

Gambar 1. menunjukkan bahwa jumlah kematian Covid tertinggi di Indonesia dibandingkan dengan negara-negara ASEAN lainnya. Berdasarkan data dari Kementrian Kesehatan pada 29 April 2020, terdapat 9.771 kasus dengan 1.391 dinyatakan sembuh dan 784 kematian (Kementrian Kesehatan, April 2020). Jumlah kasus Covid-19 tertinggi di Indonesia ditemukan di Jawa. Posisi pertama ada DKI Jakarta dengan 4.092 kasus dan 370 kematian. Jawa Barat diposisi kedua dengan 1.009 kasus dan 79 orang meninggal. Jawa Timur Ketiga adalah 872 kasus dengan 107 kematian.

Tabel 1. Kasus Covid-19 di Indonesia

\begin{tabular}{lccc}
\hline Province & Cases & Recovery & Deaths \\
\hline Jakarta & 4.092 & 440 & 370 \\
West Java & 1.009 & 107 & 79 \\
East Java & 872 & 152 & 95 \\
Central Java & 711 & 101 & 59 \\
South & 465 & 118 & 37 \\
Sulawesi & 388 & 33 & 41 \\
Banten & 2.234 & 440 & 103 \\
Others & 9.771 & 1.391 & 784 \\
\hline TOTAL & & & \\
\hline
\end{tabular}

Sumber: Kementrian Kesehatan, 29 April 2020

Covid-19 memberikan dampak signifikan terhadap perkembangan ekonomi dunia. Pandemic Covid-19 adalah tantangan bagi dunia bisnis, termasuk industri jasa keuangan perbankan. Berdasarkan data statistik perbankan Syariah pada Januari 2020, jumlah jaringan kantor Bank Umum Syariah adalah 1.922 cabang yang tersebar di berbagai wilayah di Indonesia yang didominasi oleh Pulau Jawa. Sejalan dengan wilayah terbanyak ditemukan Covid-19 yaitu di pulau Jawa (Statistik Perbankan Syariah, Januari 2020). Ini menunjukkan bahwa sebagian besar Kantor Bank Syariah berada di zona merah.

Berikut ini gambar 2. Tingkat persebaran industri perbankan Syariah di Indonesia 
Gambar. 2 Tingkat Persebaran Industri Bank Umum Syariah berdasarkan Wilayah

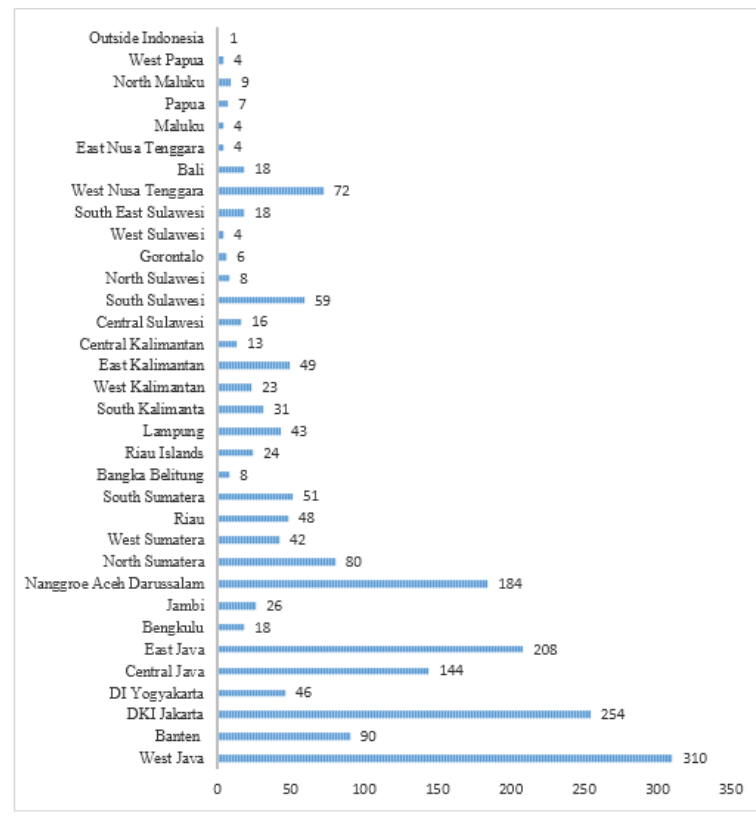

Sumber: Statistik Perbankan Syariah, Januari 2020

Gambar 2. Di atas menunjukkan bahwa tingkat persebaran lokasi perbankan Syariah terkonsentrasi dibeberapa wilayah yang termasuk dalam zona merah. Wilayah Jawa Barat terbanyak pertama dengan jumlah 310 Kantor Cabang, Jakarta terbanyak kedua dengan jumlah 254 Kantor Cabang. Jawa Timur terbanyak ketiga dengan jumlah 208 Kantor Cabang.

Bank Syariah dalam menjalankan fungsinya sebagai lembaga intermediasi atau perantara keuangan yang mempertemukan antara masyarakat yang kelebihan dana dengan masyarakat yang kekurangan dana dituntut untuk dapat berinteraksi dengan orang banyak. Namun disisi lain, ancaman terhadap paparan virus Covid-19 menjadi tantangan bagi lembaga perbankan. Berbagai kebijakanpun dikeluarkan perbankan untuk tetap dapat bertahan ditengah pandemi Covid-19.

Penelitian tentang dampak covid-19 pada industri keuangan telah dilakukan oleh Kashif Malik (2020) dengan obyek industri keuangan mikro. Zbigniew Korzeb dan Reyes Samaniego (2019) megambil obyek Bank Islam dengan fokus penelitian pada fungsi intemediasi Bank.

Penelitian ini bermaksud untuk mengetahui bagaimana manajemen strategi operasional yang diambil di masing-masing Bank Syariah dalam menjalankan fungsinya sebagai lembaga intermediasi perbankan yaitu dari sisi penghimpunan dana dan penyaluran dana pada masa pandemi Covid-19. Dan sejauh mana bank dapat menjalankan fungsi intermediasinya. Berdasarkan data statistik Perbankan Syariah Maret 2020 dari sisi penghimpunan Dana Bank Umum Syariah secara nasional menurun dari 236.447 Miliar di bulan Februari menjadi 234.240 Miliar di Maret 2020.

\section{B. METODE}

Obyek Penelitian ini adalah Bank Umum Syariah. Bank Umum Syariah dipilih dengan pertimbangan sebagai salah satu lembaga jasa keuangan yang memberikan kontribusi besar pada pertumbuhan ekonomi melalui bantuan permodalan.

Populasi dalam penelitian berjumlah 14 Bank Umum Syariah di Indonesia. Sampel penelitian diperoleh dengan menggunakan teknik purposive sampling. Purposive sampling adalah pengambilan sampel berdasarkan kriteria Bank 
Umum Syariah yang mempublikasikan laporan keuangan dari Januari hingga Maret 2020. Periode ini dipilih dengan pertimbangan sebagai waktu penyebaran Covid-19 di Indonesia. Sehingga diperoleh 5 Bank Umum Syariah diantaranya Bank Syariah Mandiri, Bank Mega Syariah, Bank Syariah Bukopin, Bank Victoria Syariah dan Bank BJB Syariah. Analisis Studi komparatif dilakukan memperbandingkan manajemen strategi operasional di Bank Umum Syariah menghadapi Pandemi Covid-19 dan dampak Covid-19 tentang kegiatan intermediasi Bank Syariah.

\section{HASIL DAN PEMBAHASAN}

Regulator mengeluarkan kebijakan untuk meminimalkan dampak Covid-19, termasuk di sektor industri perbankan. Pemerintah melalui Otoritas Jasa Keuangan mengeluarkan Kebijakan Stimulus Perekonomian Nasional Sebagai Kebijakan Countercylical Dampak Penyebaran Coronavirus Disease 2019, penerbitan POJK No.11 / POJK.03 / 2020. Kebijakan stimulus yang dimaksud terdiri atas kebijakan penilaian kualitas pembiayaan hanya didasarkan pada ketepatan pembayaran pokok dan margin/ bagi hasil/ ujrah dengan pembiayaan mencapai 10 Miliar dan Skema Restrukturisasi pembiayaan.

Restrukturisasi pembiayaan adalah bantuan pelunasan pinjaman. Restrukturisasi bukanlah penghapusan, tetapi memberikan kelonggaran untuk melunasi pembayaran utang. Pinjaman masih harus dibayar tetapi diberikan keringanan berdasarkan penilaian dan kesepakatan dengan Bank.

Relaksasi dari pengaturan ini berlaku untuk debitur Non-UKM dan UKM, dengan masa berlaku hingga satu tahun dari 13 Maret 2020 hingga 31 Maret 2021. Pelaksanaannya tergantung pada kebijaksanaan masing-masing bank.

POJK No. 18/ POJK.03/ 2020 mengambil langkah-langkah untuk menjaga stabilitas sistem keuangan, terutama di sektor perbankan, ancaman pelemahan ekonomi akibat pandemi COVID-19. OJK memberikan perintah kepada Bank untuk yang Pertama, Melakukan merger, konsolidasi, pengambilalihan, dan atau integrasi. Kedua, menerima merger, konsolidasi, akuisisi, atau integrasi.

Kebijakan selanjutnya tentang industri perbankan yang dikeluarkan oleh otoritas selama PSBB (SP 26/ DHMS/ OJK/ IV/ 2020). Menurut Siaran Pers dalam Operasi Industri Jasa Keuangan Selama Periode Implementasi PSBB di Berbagai Daerah. Isinya bahwa OJK meminta lembaga jasa keuangan untuk bekerja dengan jumlah minimum karyawan sesuai dengan protokol kesehatan di tempat kerja.

Lembaga layanan keuangan harus mematuhi prosedur PSBB untuk diimplementasikan, seperti physical distancing, mengurangi layanan dengan tatap muka dan sebagai gantinya perbankan dapat memaksimalkan penggunaan teknologi dan selalu menjaga kesehatan. Sedangkan untuk peraturan pekerjaan dari rumah, diserahkan kepada masing-masing 
Lembaga Jasa Keuangan. Sedangkan untuk pelaksanaan teknis pemberian akses dengan menunjukkan identitas karyawan dan Surat Tugas.

Tabel. 2 Ikhtisar Intermediasi Bank Syariah di Masa Pandemi Covid-19 (dalam jutaan rupiah)

\begin{tabular}{|l|c|c|}
\hline \multicolumn{1}{|c|}{ Lembaga } & DPK & Pembiayaan \\
\hline $\begin{array}{l}\text { Bank Syariah } \\
\text { Mandiri }\end{array}$ & 101.915 .689 & 75.445 .553 \\
\hline $\begin{array}{l}\text { Bank Syariah } \\
\text { Bukopin }\end{array}$ & 4.313 .004 & 4.738 .848 \\
\hline $\begin{array}{l}\text { Bank Victoria } \\
\text { Syariah }\end{array}$ & 1.447 .214 & 1.144 .428 \\
\hline $\begin{array}{l}\text { Bank Mega } \\
\text { Syariah }\end{array}$ & 6.342 .428 & 6.183 .305 \\
\hline $\begin{array}{l}\text { Bank Jabar } \\
\text { Banten } \\
\text { Syariah }\end{array}$ & 5.593 .292 & 5.386 .519 \\
\hline
\end{tabular}

Sumber: Laporan Bulanan Bank, Maret 2020

Tabel 2. Ikhtisar Intermediasi Bank Syariah di Masa Pandemi Covid-19 menunjukkan bahwa kelima Bank Syariah tetap menjalankan fungsi intermediasinya dalam kondisi pandemi Covid19.

\section{Analisis Dampak Covid pada Bank Syariah Mandiri (BSM)}

Dampak pada Kegiatan Intermediasi Bank Syariah Mandiri dilihat dari Perkembangan pembiayaan dan Dana Pihak Ketiga (DPK).

Gambar 3. Pembiayaan dan DPK Bank Syariah Mandiri menunjukkan bahwa pembiayaan Bank Syariah Mandiri meningkat selama Januari hingga Maret 2020. Namun, DPK menunjukkan fluktuatif. Ini menunjukkan bahwa Pandemic Covid-19 mengganggu Bank dari sisi Penghimpunan DPK. Sementara itu, Pembiayaan untuk Bank Syariah Mandiri cenderung stabil.
Gambar 3. Pembiayaan dan DPK Bank Syariah Mandiri

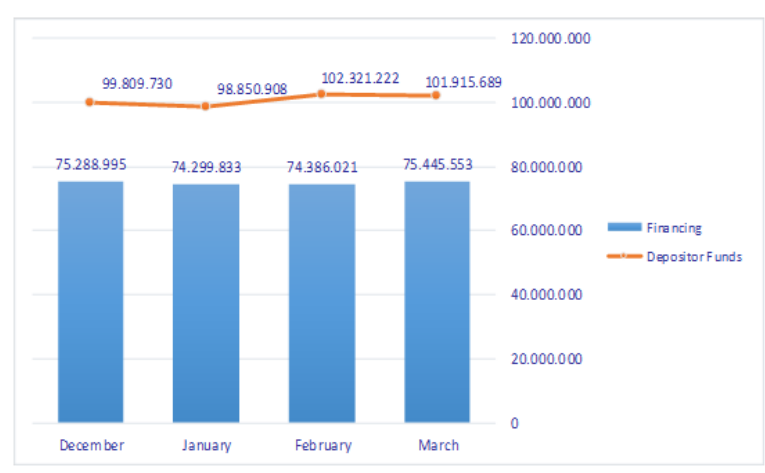

Sumber: Bank Syariah Mandiri, Maret 2020

Dampak pada Manajemen Strategi Bank Syariah Mandiri. Bank Mandiri Syariah selama pandemi Covid-19 mengeluarkan kebijakan terkait dengan produk dan layanan sebagai berikut:

Pertama, Mandiri Syariah Mobile (MSM). Mandiri Syariah Mobile disebut sebagai Superaps, yang mana satu aplikasi tidak hanya dapat melakukan transaksi keuangan tetapi juga menawarkan berbagi fitur - fitur tambahan diantaranya seperti fitur pembayaran zakat, sedekah, wakaf, serta ibadah melalui kemudahan mendapatkan jadwal sholat, arah kiblat, lokasi masjid, juz amma, kutipan hadits, dan lain-lain. Mandiri Syariah Mobile (MSM) dapat pula untuk transaksi e-commerce, pembayaran haji, top-up e-wallet (emoney, gopay, ovo).

Kedua, QRIS. Transaksi menggunakan smartphone. Quick Response Code Indonesia Standard (QRIS) memudahkan dengan gadget dan teknologi untuk melakukan transaksi melalui metode pembayaran digital QRIS. 
Ketiga, Kebijakan Stimulus Perekonomian Nasional No.11/ POJK.03/ 2020. Bank melonggarkan fasilitas pembiayaan kepada nasabah yang tedampak pandemi Covid-19 dalam bentuk penundaan pembayaran dan atau penurunan margin atau bagi hasil untuk jangka waktu tertentu dan persyaratannya disesuaikan dengan sektor ekonomi, kriteria, dan kondisi nasabah dengan tetap mengacu pada ketentuan OJK untuk nasabah terutama UKM.

\section{Analisis Dampak Covid pada Bank Syariah Bukopin (BSB)}

Dampak pada Kegiatan Intermediasi Bank Syariah Bukopin dilihat dari Perkembangan pembiayaan dan Dana Pihak Ketiga (DPK).

Gambar 4. Pembiayaan dan DPK Bank Syariah Bukopin

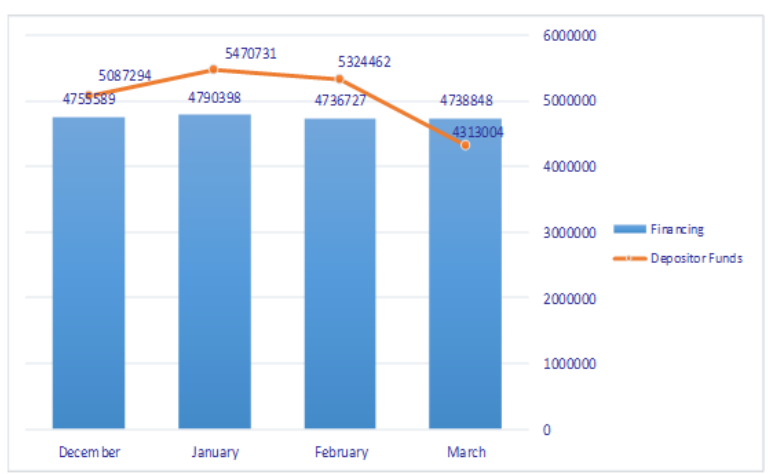

Sumber: Bank Syariah Bukopin, Maret 2020

Gambar 4. Pembiayaan dan DPK Bank Syariah Bukopin menunjukkan bahwa pembiayaan Bank Syariah Bukopin menurun selama Januari hingga Maret 2020. Hal ini sebagaimana dengan perkembangan Penghimpunan dana (DPK) yang juga menunjukkan penurunan. Ini menunjukkan bahwa Pandemic Covid-19 mengganggu fungsi intermediasi Bank Syariah Bukopin pada sisi DPK dan pembiayaan.

Dampak pada Manajemen Strategi Bank Syariah Bukopin. Bank Syariah Bukopin selama pandemi Covid-19 mengeluarkan kebijakan terkait dengan produk dan layanan sebagai berikut:

Pertama, tabungan berhadiah. Bank Syariah Bukopin Menawarkan Tabungan dengan Hadiah Langsung. Nasabah dapat memilih Sedekah sendiri sebagai bentuk kepedulian terhadap dampak pandemi Covid-19. Cara mendapatkan hadiah yaitu, nasabah membuka rekening tabungan iB SiAga atau iB SiAga Bisnis mulai dari Rp. 25 juta, nasabah dapat memberikan sedekah dan menentukan lokasi distribusinya dan dapat pula menentukan bentuknya seperti Donasi Alat Pelindung Diri (APD), vitamin, Handsanitizer, dan Makanan. Nasabah mendapatkan kartu ATM, buku tabungan dan dapat menggunakan fasilitas BSB Mobile (M-Banking).

Kedua, Pembatasan layanan operasional bank. Batasan kegiatan layanan Bank Syariah Bukopin untuk mencegah penyebaran Virus Corona (Covid-19) adalah layanan tunai pukul 08.100 - 14.00 dan layanan kantor buka dari pukul 08.00 - 15.00 .

Ketiga, Kebijakan Stimulus Perekonomian Nasional yaitu No.11/ POJK.03/ 2020. Bank melonggarkan fasilitas pembiayaan kepada nasabah yang tedampak pandemi Covid-19 dalam bentuk penundaan pembayaran dan atau penurunan margin atau bagi hasil untuk jangka waktu tertentu dan persyaratannya disesuaikan 
dengan sektor ekonomi, kriteria, dan kondisi nasabah dengan tetap mengacu pada ketentuan OJK untuk nasabah terutama UKM.

Keempat, Program Bank Syariah Bukopin Peduli Pandemi Covid-19. Bank Syariah Bukopin melakukan kegiatan sosial dalam bentuk bantuan makanan langsung kepada masyarakat yang kurang mampu atau mereka yang terkena dampak langsung oleh pandemi COVID-19 di sekitar kantor Bank Syariah Bukopin. Bantuan bantuan langsung ini terdiri dari paket-paket makanan pokok seperti beras, minyak, gula pasir, minyak goreng, dan lainnya.

\section{Analisis Dampak Covid pada Bank Victoria Syariah}

Dampak pada Kegiatan Intermediasi Bank Victoria Syariah dilihat dari Perkembangan pembiayaan dan Dana Pihak Ketiga (DPK).

Gambar 5. Pembiayaan dan DPK Bank Victoria Syariah

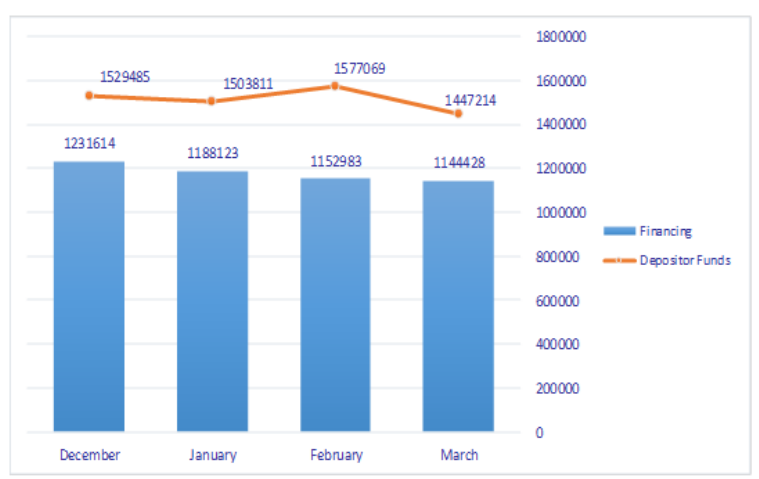

Sumber: Bank Victoria Syariah, Maret 2020

Gambar 5 menunjukkan bahwa pembiayaan Bank Victoria Syariah menurun selama Januari hingga Maret 2020. Sementara itu, Penghimpun dana (DPK) menunjukkan fluktuatif. Ini menunjukkan bahwa fungsi intermediasi Bank victoria Syariah di masa Pandemic Covid-19 terganggu dari sisi Pembiayaan dan DPK.

Dampak pada Manajemen Strategi Bank Victoria Syariah. Bank Victoria Syariah selama pandemi Covid-19 mengeluarkan kebijakan terkait dengan produk dan layanan sebagai berikut:

Pertama, Kebijakan Stimulus Perekonomian Nasional yaitu No.11/ POJK.03/ 2020. Bank melonggarkan fasilitas pembiayaan kepada nasabah yang tedampak pandemi Covid-19 dalam bentuk penundaan pembayaran dan atau penurunan margin atau bagi hasil untuk jangka waktu tertentu dan persyaratannya disesuaikan dengan sektor ekonomi, kriteria, dan kondisi nasabah dengan tetap mengacu pada ketentuan OJK untuk nasabah terutama UKM.

Kedua, Shariah Cares Covid-19. Penyaluran layanan sosial 500 APD ke 20 Rumah Sakit di Jabodetabek dan Jawa Barat Banten. Bank Victoria Syariah pada program Shariah Cares Covid-19 ini bekerja sama dengan ASBISINDO dari Asosiasi Bank Syariah Indonesia.

\section{Analisis Dampak Covid pada Bank Mega Syariah}

Dampak pada Kegiatan Intermediasi Bank Mega Syariah dilihat dari Perkembangan pembiayaan dan Dana Pihak Ketiga (DPK).

Gambar 6. Pembiayaan dan DPK Bank Mega Syariah menunjukkan bahwa pembiayaan Bank Mega Syariah meningkat selama Januari hingga Maret 2020. Namun, penghimpunan dana (DPK) menunjukkan fluktuatif. Ini menunjukkan bahwa Pandemic Covid-19 mengganggu Bank dari sisi 
Penghimpunan dana (DPK). Sementara itu, Pembiayaan untuk Bank Mega Syariah cenderung stabil.

Gambar 6. Pembiayaan dan DPK Bank Mega Syariah

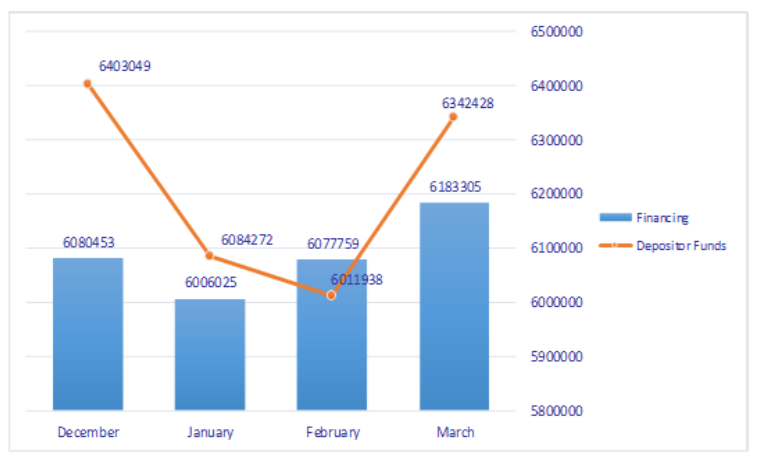

Sumber: Bank Mega Syariah, Maret 2020

Dampak pada Manajemen Strategi Bank Mega Syariah. Bank Mega Syariah selama pandemi Covid-19 mengeluarkan kebijakan terkait dengan produk dan layanan sebagai berikut:

Pertama, Mega Syariah Mobile. Aplikasi Mega Syariah Mobile adalah fasilitas mobile banking digital yang dapat digunakan nasabah selama pandemi bekerja dari rumah. Salah satu fasilitas yang dapat digunakan di Mega Syariah Mobile adalah pembayaran biaya kuliah online dan lain - lain.

Kedua, Kebijakan Stimulus Perekonomian Nasional yaitu No.11/ POJK.03/ 2020. Bank melonggarkan fasilitas pembiayaan kepada nasabah yang tedampak pandemi Covid-19 dalam bentuk penundaan pembayaran dan atau penurunan margin atau bagi hasil untuk jangka waktu tertentu dan persyaratannya disesuaikan dengan sektor ekonomi, kriteria, dan kondisi nasabah dengan tetap mengacu pada ketentuan OJK untuk nasabah terutama UKM.

\section{Analisis Dampak Covid pada BJB Syariah}

Dampak pada Kegiatan Intermediasi BJB Syariah dilihat dari Perkembangan pembiayaan dan Dana Pihak Ketiga (DPK).

Gambar 7. Pembiayaan dan DPK BJB Syariah

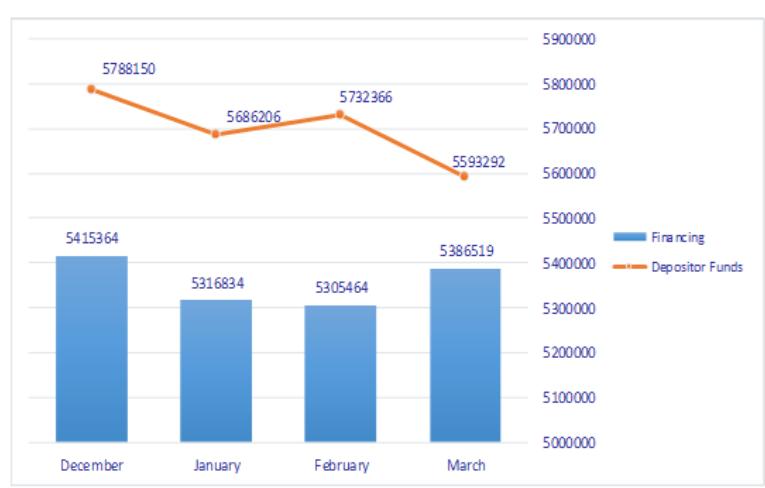

Sumber: BJB Syariah, Maret 2020

Gambar 7 menunjukkan pembiayaan dan DPK BJB Syariah selama Januari hingga Maret 2020 fluktuatif. Ini menunjukkan bahwa Pandemic Covid-19 mengganggu fungsi intermediasi BJB Syariah dari penghimpunan dana (DPK) dan pembiayaan.

Dampak pada Manajemen Strategi Bank. Bank BJB Syariah selama pandemi Covid-19 mengeluarkan kebijakan terkait dengan produk dan layanan sebagai berikut:

Pertama, Mobile Banking Maslahah. Layanan perbankan bagi nasabah untuk dapat melakukan transaksi sesuai dengan kebutuhan dan dapat dilakukan di rumah. Bank BJB Syariah memiliki aplikasi Mobile Maslahah yang dapat digunakan nasabah untuk bertransaksi. Mobile Maslahah memiliki berbagai fitur diantaranya cek saldo, 
lokasi ATM terdekat, pembayaran tagihan rutin bulanan, pembelian voucher dan lain - lainnya.

Kedua, Kebijakan Stimulus Perekonomian Nasional yaitu No.11/ POJK.03/ 2020. Bank melonggarkan fasilitas pembiayaan kepada nasabah yang tedampak pandemi Covid-19 dalam bentuk penundaan pembayaran dan atau penurunan margin atau bagi hasil untuk jangka waktu tertentu dan persyaratannya disesuaikan dengan sektor ekonomi, kriteria, dan kondisi nasabah dengan tetap mengacu pada ketentuan OJK untuk nasabah terutama UKM.

\section{PENUTUP}

\section{Kesimpulan}

Dampak Pandemi Covid-19 terhadap fungsi intermediasi perbankan, berdasarkan hasil studi komparatif pada Bank Syariah Mandiri, Bank Mega Syariah, Bank Syariah Bukopin, Bank Victoria Syariah dan BJB Syariah menunjukkan bahwa fungsi intermediasi Bank, yaitu Pembiayaan dan DPK, semua Bank menunjukkan adanya gejolak. Pada sisi pembiayaan Bank Syariah Mandiri dan Bank Mega Syariah selama Januari hingga Maret 2020 cenderung meningkat. Sementara itu, Bank Bukopin Syariah, Victoria Bank Syariah dan Bank BJB Syariah menunjukkan fluktuatif.

Pada sisi Penghimpunan Dana (DPK), Bank Syariah Bukopin menunjukkan penurunan selama Januari hingga Maret 2020. Sementara itu, Bank Mandiri Syariah, Bank Mega Syariah, Bank Syariah BJB, dan Bank Victoria Syariah menunjukkan fluktuatif.
Dampak Pandemi Covid-19 terhadap manajemen strategi operasional perbankan. Berdasarkan hasil studi komparatif pada Bank Syariah Mandiri, Bank Mega Syariah, Bank Syariah Bukopin, Bank Victoria Syariah dan Bank BJB Syariah menunjukkan bahwa: Pertama, semua bank menerapkan stimulus ekonomi terkait pembiayaan restrukturisasi untuk Nasabah yang terkena dampak pandemi Covid19 berdasarkan POJK No.11/ POJK.03/ 2020. Kedua, pengembangan aplikasi digital mobile banking pada kelima bank Syariah.

\section{Keterbatasan dan Saran Penelitian}

Penelitian ini menggunakan sampel lima Bank Umum Syariah di Indonesia karena keterbatasan data bank. Diiharapkan penelitian selanjutnya dapat dilakukan di semua Bank Umum Syariah di Indonesia yaitu 14 Bank Umum Syariah sehingga dapat menggeneralisasi hasil penelitian.

\section{DAFTAR PUSTAKA}

Kashif Malik, et. al. (2020). Covid-19 and the Future of Microfinance: Evidence and Insights from Pakistan, Forthcoming Oxford Review of Economic Policy (Special Issue).

Kementrian Kesehatan. (2020). Kasus Covid-19 on 29 April 2020. http://kemkes.go.id.

Laporan Keuangan Bulanan. Desember 2019, Januari, Februari and Maret 2020. Website Bank Jabar Banten Syariah. http://bjbsyariah.co.id

Laporan Keuangan Bulanan. Desember 2019, Januari, Februari and Maret 2020. 
Website Bank Mega Syariah, Otoritas Jasa Keuangan. (2019).Statistik http://megasyariah.co.id

Perbankan Indonesia January 2019.

Laporan Keuangan Bulanan. Desember 2019, Januari, Februari and Maret 2020. Website Bank Syariah Bukopin, http://syariahbukopin.co.id

Montly Financial Statement December 2019, January, February and March 2020 on Website Bank Syariah Mandiri, http://mandirisyariah.co.id

Laporan Keuangan Bulanan. Desember 2019, Januari, Februari and Maret 2020. Website Bank Victoria Syariah, http://bankvictoriasyariah.co.id

Mahinda Mailagaha Kumbure, et al. (2020). Relation between managerial cognition and industrial performance: An Assessment with Strategic Cognitive Maps using Fuzzy-set qualitative comparative Analysis. Otoritas Jasa Keuangan. (2020). POJK No. 11/POJK.03/2020 tentang Stimulus Perekonomian Nasional Sebagai Kebijakan Countercyclical Dampak Penyebaran Coronavirus Disease

Otoritas Jasa Keuangan. (2020). Siaran Pers OJK SP 26/DHMS/OJK/IV/ 2020 tentang Siaran Pers Operasional Industri Jasa Keuangan Dalam Masa Penerapan Pembatasan Sosial Berskala Besar (PSBB) Di Berbagai Daerah

Otoritas Jasa Keuangan. (2020). POJK No. 18 / POJK.03/2020 tentang PerintahTertulis untuk Penanganan Permasalahan Bank

Zbigniew Korzeb and Reyes Samaniego - Medina, Sustainability Performance: A Comparative Analysis in The Polish Banking Sector, Sustainability, 2019 Journal of Business Research.Elsevier. 